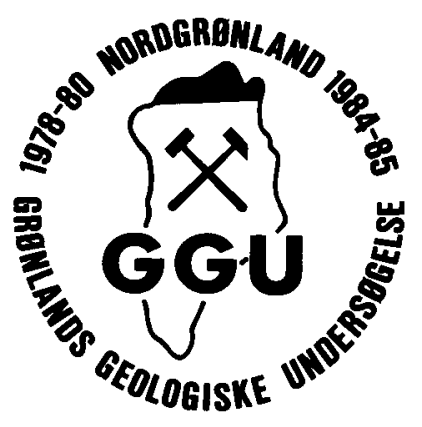

\title{
The North Greenland fold belt in eastern Nansen Land
}

\author{
Johan D. Friderichsen and \\ Hans-Jørgen Bengaard
}

\begin{abstract}
Field work in 1984 shows that Nansen Land consists of clastic rocks of the carbonaceous Paradisfjeld Group and terrigeneous rocks of the Polkorridoren Group; both are lower Cambrian in age and deposited in a slope and fan environment. Two major Ellesmerian (Devonian to Carboniferous) phases of deformation gave rise to east-west trending folds and schistosities. Three phases of Eurekan (upper Cretaceous to Tertiary) deformation, associated with dyke intrusion, are recognised. The second of these may be related to transpression on the Harder Fjord fault zone, though no major strike-slip movement seems to have taken place.
\end{abstract}

J. D. F. \& H.-J. B., Grønlands Geologiske Undersøgelse, Øster Voldgade 10, DK-1350 Copenhagen K, Denmark.

Deformed early Cambrian sediments make up the north coastal region of North Greenland between north-east Peary Land and Nyeboe Land. Thick sequences of resedimented carbonates and terrigeneous clastics were deposited in a roughly east-west trending trough (Surlyk \& Hurst, 1984), which was the eastward extension of the lower Palaeozoic Hazen trough of Arctic Canada (Trettin \& Balkwill, 1979). The North Greenland fold belt subsequently developed on the site of the trough.

This report concerns work in eastern Nansen Land north of the major valley connecting J. P. Koch Fjord and southern Brainard Sund (fig. 1).

\section{Stratigraphy}

The sediments of the North Greenland trough were subdivided into six groups by Friderichsen et al. (1982), but only two of these, the Paradisfjeld Group and the Polkorridoren Group, have been found in eastern Nansen Land. The older of these, the Paradisfjeld Group, is exposed in an axial culmination in central Nansen Land and the islands east of Nansen Land; this culmination is here termed the Nansen Land anticlinorium.

As in Johannes V. Jensen Land (Higgins et al., 1981), the Paradisfjeld Group may be subdivided into a lower unit of mainly dark weathering carbonates and an upper unit of mainly light weathering carbonates. The Polkorridoren Group comprises mainly terrigeneous clastics which, in Nansen Land, have been subdivided into five informal units. The distribution of the five units in eastern Nansen Land is shown in fig. 1, and their deduced relationships in fig. 2. The Paradisfjeld Group and the Polkorridoren Group are regarded as the deep-water 


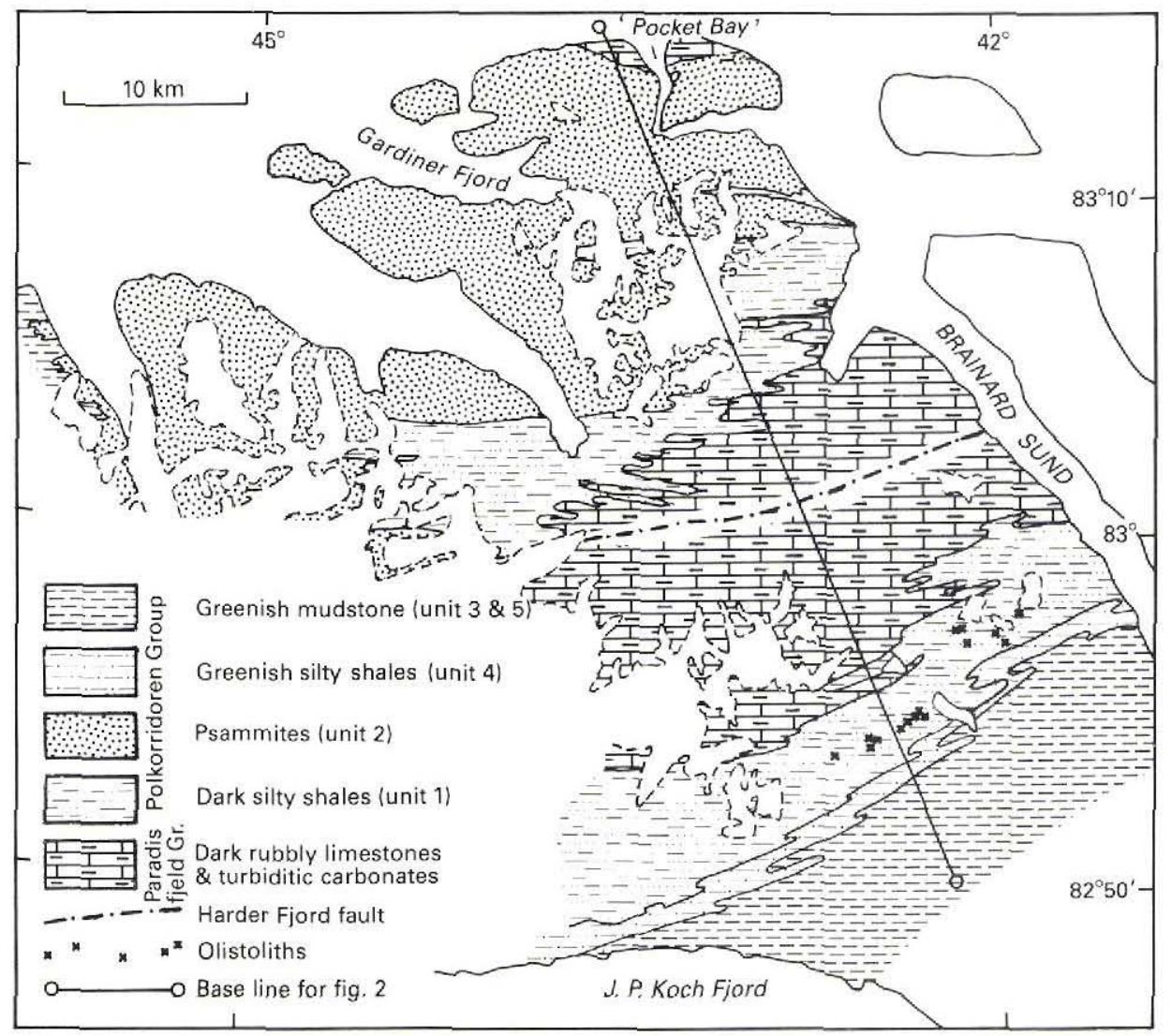

Fig. 1. Geological map of eastern Nansen Land.

equivalents of, respectively, the Portfjeld Formation and the Buen Formation of the North Greenland shelf sequence. A lower Cambrian age is well established for the Buen Formation, and the Portfjeld Formation is probably lower Cambrian throughout (Peel, 1982).

\section{Lower Paradisfjeld Group}

Dark, rubbly limestone and orange-weathering, thin-bedded, turbiditic carbonate are the two dominating lithologies of the lower Paradisfjeld Group. Other rock types include phyllite and calc-phyllite, and matrix-supported conglomerate. A few large $(50 \mathrm{~m})$ limestone blocks of possibly exotic origin have also been noted. In the dark rubbly limestone, deformation and recrystallisation has obliterated most sedimentary features, but the general impression is that many of these rocks are badly sorted, resedimented pisolitic packstones or wackestones.

Due to poor exposures and rather tight folding it has not been possible to make any strati- 


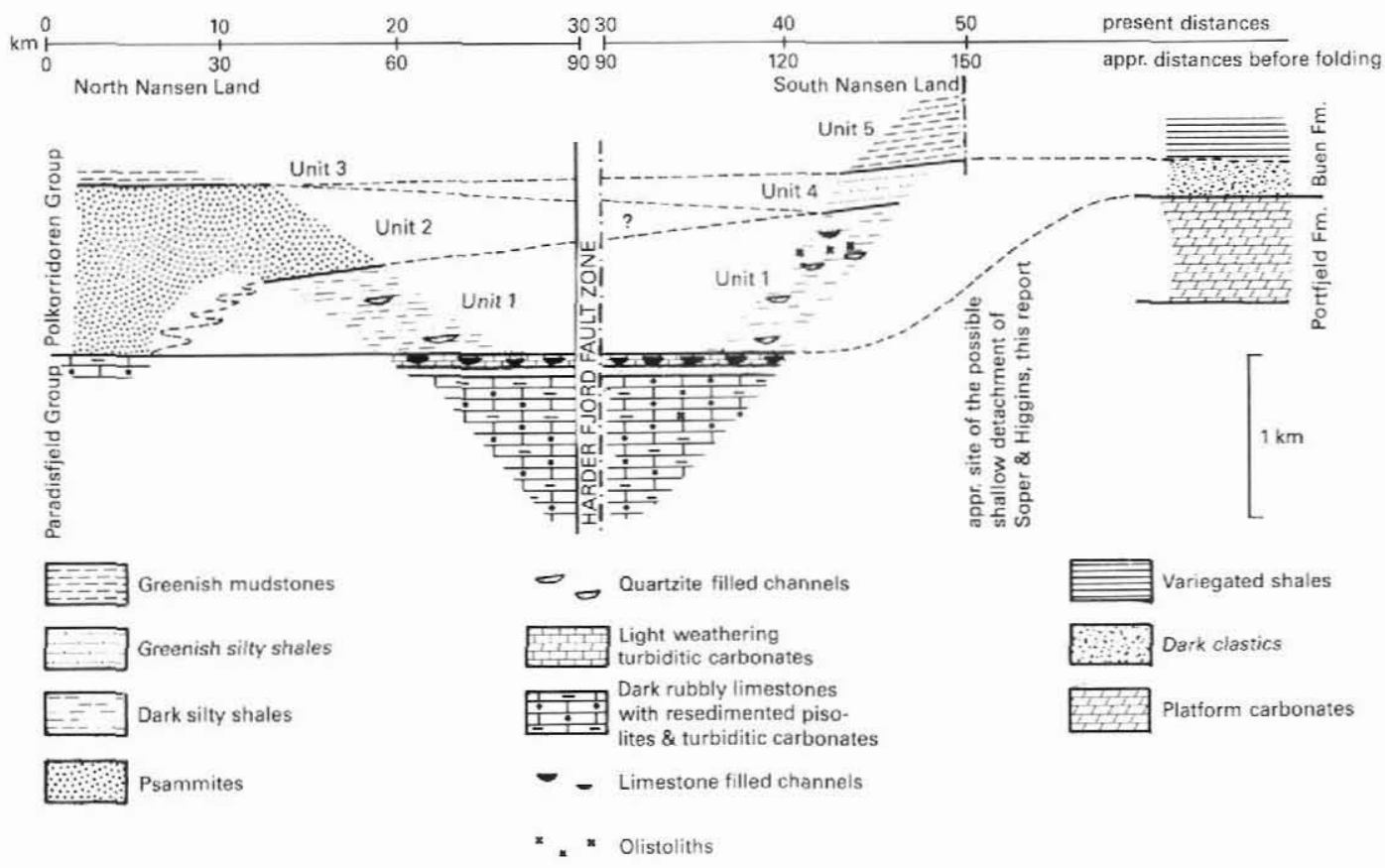

Fig. 2. Stratigraphic sketch profile across eastern Nansen Land. See fig. 1 for base line. Unit 3 is extrapolated from the west.

graphical subdivision of the lower Paradisfjeld Group. Its base was not seen, but the total exposed thickness probably exceeds $1 \mathrm{~km}$.

A slope environment may be inferred for the deposition of the lower Paradisfjeld Group (cf. Surlyk \& Hurst, 1984). The basin/shelf transition may have followed the major valley connecting J. P. Koch Fjord and Brainard Sund as stromatolitic Portfjeld Formation is present just to the south of this valley (Higgins \& Soper, 1985).

\section{Upper Paradisfjeld Group}

Light weathering carbonates of the upper Paradisfjeld Group form a very convenient marker horizon. There are three dominant lithologies: massive, light grey and weakly conglomeratic carbonates with lateral thickness variations between 0 and $50 \mathrm{~m}$, probably of debris flow, channel fill origin; bright orange weathering, thin-bedded turbiditic carbonates, mostly of silt grade; and an orange weathering carbonate conglomerate with matrix-supported carbonate clasts. The total thickness of the upper Paradisfjeld Group is up to $150 \mathrm{~m}$. The boundary between the upper and the lower Paradisfjeld Group is usually sharp and conformable.

The association of channellised debris flows and thin-bedded, silty turbidites suggests an upper fan environment for the deposition of the upper Paradisfjeld Group. 


\section{Polkorridoren Group, unit 1}

Dark, silty shales with a good proportion of thin, turbiditic sandstones are the dominant lithologies of unit 1 (figs $1 \& 2$ ). However, sequences of coarse-grained, thick-bedded quartzites also occur, notably to the east. Individual quartzite beds are generally massive throughout or horizontally laminated in the upper part. The quartzite sequences are up to $50 \mathrm{~m}$ thick; they wedge out and replace each other laterally and are interpreted as channel fills.

A horizon in unit 1 contains exotic blocks of carbonate rocks up to $300 \mathrm{~m}$ across. The carbonate blocks include lithologies similar to the Portfjeld Formation of the North Greenland shelf (H. F. Jepsen \& J. S. Peel, personal communication). The blocks are confined to the south-eastern part of the area mapped; the distribution of the larger blocks is shown on fig. 1. The boundaries of the blocks to the surrounding siltstones are poorly exposed, but in a few places slumped and deformed siltstones have been seen to underlie them.

A minor part of unit 1 is made up of horizons of thin-bedded limestone turbidites, carbonate cemented sandstones and calcareous shales.

The thickness of unit 1 in the southern part of Nansen Land is $c .1 \mathbf{k m}$; it is thinner to the north and seems to have wedged out around Pocket Bay. Unit 1 rests conformably upon the upper Paradisfjeld Group; the boundary is usually transitional over a few metres; orange weathering, thin-bedded silty carbonates grade upwards into dark, terrigeneous siltstones of unit 1.

A slope environment is inferred for the deposition of the major part of unit 1 . In easternmost Nansen Land the quartzitic channel fills suggest the existence of a submarine fan. The significance of the exotic blocks (olistoliths) is not clear, and several models may be proposed for their emplacement. They may have broken off from a fault scarp along the shelf margin to the south, as suggested by N. J. Soper \& A. K. Higgins (personal communication). However, as they seem to be concentrated in the upper part of the submarine fan mentioned above, a model relating them to a submarine canyon, feeding this fan, might be more appropriate. They could have been dislodged from the sides of such a canyon, possibly in connection with faulting oblique to the shelf margin. Alternatively, they could have originated as megabreccias of the same nature as the approximately contemporaneous megabreccias found at the head of Victoria Fjord (H. F. Jepsen, personal communication). Blocks from such megabreccias could have been transported through the canyon to the fan.

More information on the regional distribution of the megabreccias will be necessary to choose between these models.

\section{Polkorridoren Group, unit 2}

Monotonous thick-bedded and coarse-grained psammites and thin interleaving siltstones make up the bulk of unit 2 (figs $1 \& 2$ ). The psammites are rich in feldspar grains and matrix; recrystallisation has often destroyed most of the finer sedimentary structures. Individual beds are graded and range in thickness from 0.5 to $4 \mathrm{~m}$; at some localities, sequences of psammite beds show fining/thinning upwards arrangements ending with black siltstone. The total thickness of unit 2 exceeds $1 \mathrm{~km}$. The lower boundary of unit 2 is usually scree-covered, and it is not known whether unit 2 interfingers with unit 1 or overlies it conformably.

A midfan and outer fan environment is inferred for the deposition of unit 2 . The mineralogical difference between the feldspar-bearing psammites of this unit and the pure, coarse- 
grained channel fill quartzites of unit 1 suggests, however, that the submarine fan present in unit 1 was distinct from the fan(s) depositing unit 2 . The distinction between psammites and pure quartzites has also been recorded in Johannes $\mathrm{V}$. Jensen Land, possibly also here signifying that the coarser sediments supplied to the trough from the south were pure quartzites. It is therefore tentatively suggested that the feldspar bearing psammites of unit 2 , and the comparable psammites in the rest of the North Greenland trough, may not have been derived from the south, but rather from sources to the north and north-east of the trough.

Unit 1 and unit 2 make up a lower division of the Polkorridoren Group in Nansen Land. The shelf margin during their deposition was probably situated a few kilometres south of the major valley connecting J. P. Koch Fjord and Brainard Sund where a facies transition occurs in the lower part of the Buen Formation (Higgins \& Soper, 1985).

\section{Polkorridoren Group, unit 4}

The greenish silty shales with thin, fine-grained quartzites of unit 4 typically contain thin, rusty carbonate schlieren. Flute casts have been noted, as well as ripple lamination. There are gradational transitions into units 1 and 5 . A thickness of $200-300 \mathrm{~m}$ is present in southern Nansen Land (figs 1 \& 2).

\section{Polkorridoren Group, units 3 and 5}

Greenish mudstones of units 3 and 5, and their metamorphic equivalents, are strongly cleaved but otherwise structureless. Unit 5 can be safely correlated with the Frigg Fjord mudstone of Johannes V. Jensen Land (Higgins et al., 1981); the correlation between unit 3 and unit 5 suggested on fig. 2 is, however, uncertain. No thickness estimate of unit 3 can be given at present. The apparent thickness of the strongly recrystallised unit 5 exceeds $600 \mathrm{~m}$; the original thickness cannot be determined, however, because of strong deformation.

Units 3, 4 and 5 possibly represent a late stage in the deposition of the Polkorridoren Group when the supply of coarse clastics had decreased in this region.

\section{Structural and metamorphic development}

The main deformation of the North Greenland fold belt occurred during the Ellesmerian orogeny which, in North Greenland, is thought to be of upper Devonian to lower Mississipian age (Springer, 1981). Later deformations were probably confined to late Cretaceous to early Tertiary time and relate to the Eurekan orogeny of Arctic Canada (Balkwill, 1978). Major Eurekan structures in North Greenland include the Harder Fjord fault zone, the Kap Cannon thrust zone, and faults and folds deforming the Wandel Sea basin sediments in eastern Peary Land (Soper et al., 1982; Håkansson \& Pedersen, 1982). Several events in Nansen Land can be referred to this later orogenic episode.

\section{Ellesmerian deformation and recrystallisation}

Three phases of deformation in Nansen Land called D1, D2 and D3 can be correlated with the Ellesmerian deformation phases distinguished in northern Peary Land (Dawes \& Soper, 1979; Soper et al., 1980; Higgins et al., 1981). 
The first phase of deformation (D1) gave rise to folds (F1) with an accompanying axial plane cleavage (S1). The F1 folds are the dominant structures in Nansen Land and are generally rather simple, long-limbed folds with amplitudes of up to $2 \mathrm{~km}$.

The F1 folds trend E-W to ENE-WSW, plunging up to $20^{\circ} \mathrm{E}$ or W. South of the central Nansen Land anticlinorium, F1 folds are asymmetrical and SSE-verging, with axial planes inclined at $75-85^{\circ}$ to the NNW. Towards the north they become gradually steeper until $c .6$ $\mathrm{km}$ south of the site of the present Harder Fjord fault where upright, symmetrical folds are present. Farther north, over a distance of a few kilometres, folds become strongly NNW-verging, with axial planes dipping approximately $30^{\circ}$ to the SSE. There is some evidence that this is due to a northward rotation of originally upright folds in connection with northerly thrusting on the site of the present Harder Fjord fault (see below). North of the present Harder Fjord fault the folds again become gradually steeper, and up to the head of Gardiner Fjord axial planes dip southwards at $50-80^{\circ}$. Near the Arctic Ocean, axial planes with both steep and flat-lying orientations are present, but poor exposure and the masking effect of the abundant dykes in this area make interpretation difficult.

The F1 folds are associated with an $\mathrm{S} 1$ axial plane cleavage. This is a pervasive slaty cleavage in the fine-grained lithologies (units 4 and 5) in the southernmost areas; in the major valley connecting J. P. Koch Fjord and Brainard Sund it is associated with chloritoid and in places a little biotite, indicating medium greenschist facies metamorphic conditions. Further to the north $\mathrm{S} 1$ is present as a slaty cleavage in the fine-grained lithologies, but only in the cores of folds. Here it is associated with the growth of white mica and chlorite; in general, however, detrital textures are still well preserved, and only incipient metamorphism is present.

Soper \& Higgins (1985) show that the deformation south of Nansen Land takes the form of thin-skinned thrusting, and suggest that a major thrust of D1 age is present in the subsurface below Nansen Land. Their model predicts that this thrust comes to the surface in the major valley connecting J. P. Koch Fjord and Brainard Sund. Much of the valley is covered by Quaternary deposits, but in the exposures of the country rock (unit 5) so far visited by us, a steep NNW-dipping S1 cleavage is the only D1 structure seen. No obvious thrusts have been found.

The second phase of deformation (D2) produced a schistocity (S2) which is well developed in the massive psammites of the Polkorridoren Group (unit 2) in northern Nansen Land. An S2 crenulation cleavage is sporadically developed in the fine-grained lithologies to the south. S2 strikes approximately E-W and dips south at $15^{\circ}$ to $40^{\circ}$.

In the massive psammites, $\mathrm{S} 2$ is partly an oriented recrystallisation of the matrix, partly an anastomosing network of millimetre-scale bands rich in white mica and chlorite or biotite. The biotite isograde is not well defined, however. Thin section studies suggest that pressure solution may have played a large role in the formation of this schistosity. In northern Nansen Land, S2 is occasionally sufficiently strong for detrital textures to be destroyed, while in the southern areas no appreciable metamorphism is associated with S2.

A zone on both sides of the presumably much younger Harder Fjord fault displays flat-lying, north-verging major folds as described above. Bands of limestone mylonite up to $50 \mathrm{~m}$ thick are also found in this zone. They strike ENE-WSW and contain a lineation plunging south at $10^{\circ}$ to $40^{\circ}$. It is tentatively suggested that these mylonites represent planes of north- 
ward-directed D2 thrusting and that D2 shearing is responsible for the strong northerly vergence of the major folds in this zone.

Otherwise very little folding is associated with the S2 schistosity in Nansen Land, in contrast to Johannes V. Jensen Land (Higgins et al., 1981). The few minor folds and kinks observed indicate a southward direction of transport, and could be related to stress relaxation at the end of the postulated thrusting episode. We have seen no evidence of major D2 northward rotation of F1 folds outside the vicinity of the present Harder Fjord fault.

It is stressed that although the presence of the Ellesmerian mylonites and the younger Harder Fjord fault within the same zone is hardly coincidental, we have seen no evidence for pre-Tertiary movements on the Nansen Land segment of the present Harder Fjord fault.

The third phase of deformation (D3) has only been recorded at the northern end of 'Pocket Bay', the northern extremity of Nansen Land. The strongly recrystallised psammites here were seen to contain a well developed crenulation cleavage (S3), cutting the rocks into microlithons and associated with development of white mica and chlorite. S3 trends at $100^{\circ}$ with a north dip of $75^{\circ}$ and can be correlated with the S3 schistocity in Johannes V. Jensen Land.

\section{Late Cretaceous and Tertiary events}

Three events of general Eurekan age are recognised in Nansen Land. Each of them seems to be associated with the intrusion of basic dykes.

The first event is marked by the intrusion of a very dense swarm of $\mathrm{N}-\mathrm{S}$ oriented dykes in the northernmost $10 \mathrm{~km}$ of Nansen Land; they are part of a swarm that can be followed eastwards at least as far as Benedict Fjord (Soper et al., 1982). The swarm reflects an episode of E-W tension (see fig. $3 a$ ) extending the crust by up to 50 percent.

The dykes are usually somewhat altered and slickensided. Non-porphyritic dykes are most abundant, but porphyritic types are also present. The dykes are alkaline (Soper et al., 1982) and related to, but slightly older than, the peralkaline Kap Washington Group volcanics, dated as latest Cretaceous (Larsen et al., 1978; Batten et al., 1981).

The second event includes compressive deformation seemingly corresponding to the regional stress-field sketched in fig. 3b. In Nansen Land the most important structures are located in a zone along the Harder Fjord fault. Here medium-scale folds are found with subhorizontal axes trending $\mathrm{N} 30^{\circ} \mathrm{E}$. The folds are upright or overturned to the NW. In places a cleavage corresponding to these folds has been seen.

The folds are thought to be related to the intrusion of a swarm of NW-SE to WNW-ESE oriented dykes which occur all over the area but are most common in a zone north of the Harder Fjord fault. They are brown weathering and usually fresh. Non-porphyritic and slightly porphyritic types occur. At a single locality a fresh NW-SE dyke was seen to cut altered N-S dykes.

In the western part of Johannes V. Jensen Land NW-SE trending faults occur (Higgins et al., 1981). They are associated with minor thrusts in the vicinity of the Harder Fjord fault and probably with the major thrusts at Kap Cannon/Lockwood $\varnothing$.

It is suggested that all these structures are related and reflect an episode of transpression 


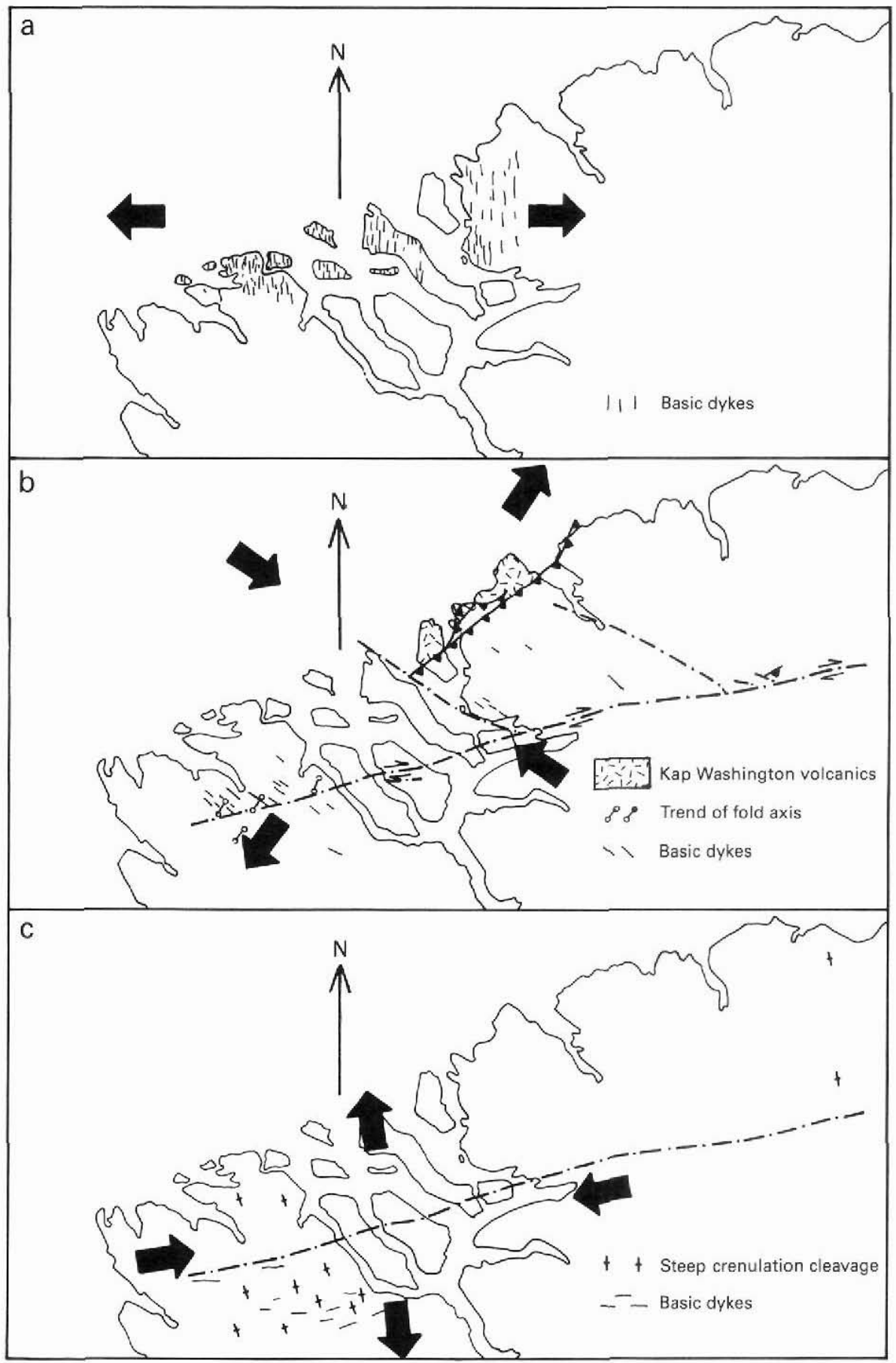

Fig. 3. Eurekan events in Nansen Land. 
on the Harder Fjord fault, as indicated in fig. 3. Tertiary strike-slip movement on the Harder Fjord fault has been estimated to be approximately $20 \mathrm{~km}$ dextral (A. K. Higgins, personal communication) based on some disruption of the central Nansen Land anticlinorium. It should, however, be noted that thrusting during the second phase of Ellesmerian deformation could account for the apparent strike-slip movement.

The Harder Fjord fault in Nansen Land is a much less spectacular feature than in Johannes V. Jensen Land. It is reduced to a narrow zone (less than $50 \mathrm{~m}$ across) of breccias and altered and slickensided dykes.

The age of the second event must be Tertiary since it post-dates the Kap Washington volcanics of latest Cretaceous age. In eastern Peary Land possibly related movements are dated as pre-late Paleocene (Håkansson \& Pedersen, 1982).

The third event affected the whole area. A steep crenulation cleavage with a general direction of roughly $160^{\circ}$ is common, particularly to the south. Occasionally it is axial planar to minor open folds and kinks. It is thought to be related to the intrusion of a swarm of E-W to ENE-WSW dykes which occur south of the Harder Fjord fault (see fig. 3c). In the field these dykes are similar to the NW-SE dykes, though no porphyritic types were found.

The dating of the third event relative to the second event is based on a single locality where two crenulation cleavages were seen to cross each other. More information is necessary before their relative ages can be firmly established.

\section{References}

Balkwill, H. R. 1978: Evolution of Sverdrup Basin, Arctic Canada. Bull. Am. Ass. Petrol. Geol. 62, 1004-1028.

Batten, D. J., Brown, P. E., Dawes, P. R., Higgins, A. K., Koch, B. E., Parsons, I. \& Soper, N. J. 1981: Peralkaline volcanicity on the Eurasia Basin margin. Nature 294, 150-152.

Dawes, P. R. \& Soper, N. J. 1979: Structural and stratigraphical framework of the North Greenland fold belt in Johannes V. Jensen Land, Peary Land. Rapp. Grønlands geol. Unders. 93, 40 pp.

Friderichsen, J. D., Higgins, A. K., Hurst, J. M., Pedersen, S. A. S., Soper, N. J. \& Surlyk, F. 1982: Lithostratigraphic framework of the Upper Proterozoic and Lower Palaeozoic deep water clastic deposits of North Greenland. Rapp. Grønlands geol. Unders. 107, $20 \mathrm{pp}$.

Higgins, A. K. \& Soper, N. J. 1985: Cambrian - Lower Silurian slope and basin stratigraphy between northern Nyeboe Land and western Amundsen Land, North Greenland. Rapp. Grønlands geol. Unders. 126, 79-86.

Higgins, A. K., Friderichsen, J. D. \& Soper, N. J. 1981 : The North Greenland fold belt between central Johannes V. Jensen Land and eastern Nansen Land. Rapp. Grønlands geol. Unders. 106, 35-45.

Håkansson, E. \& Pedersen, S. A. S. 1982: Late Paleozoic to Tertiary tectonic evolution of the continental margin in North Greenland. In Embry, A. F. \& Balkwill, H. R. (edit.) Arctic geology and geophysics. Mem. Can. Soc. Petrol. Geol. 8, 331-348.

Larsen, O., Dawes, P. R. \& Soper, N. J. 1978: Rb/Sr age of the Kap Washington Group, Peary Land, North Greenland, and its geotectonic implications. Rapp. Grønlands geol. Unders. 90, 115-119.

Peel, J. S. 1982: The Lower Palaeozoic of Greenland. In Embry, A. F. \& Balkwill, H. R. (edit.) Arctic geology and geophysics. Mem Can. Soc. Petrol. Geol. 8, 309-320.

Peel, J. S. \& Wright, S. C. 1985: Cambrian platform stratigraphy in the Warming Land - Freuchen Land region, North Greenland. Rapp. Grønlands geol. Unders. 126, 17-24.

Soper, N. J. \& Higgins, A. K. 1985: Thin-skinned structures at the basin-shelf transition in North Greenland. Rapp. Grønlands geol. Unders. 126, 87-94. 
Soper, N. J., Higgins, A. K. \& Friderichsen, J. D. 1980: The North Greenland fold belt in eastern Johannes V. Jensen Land. Rapp. Grønlands geol. Unders. 99, 89-98.

Soper, N. J., Dawes, P. R. \& Higgins, A. K. 1982: Cretaceous-Tertiary magmatic and tectonic events in North Greenland and the history of adjacent ocean basins. In Dawes, P. R. \& Kerr, J. W. (edit.) Nares Strait and the drift of Greenland: a conflict in plate tectonics. Meddr Grønland, Geosci. 8, 205220.

Springer, N. 1981: Preliminary Rb-Sr age determinations from the North Greenland fold belt, Johannes V. Jensen Land. Rapp. Grønlands geol. Unders. 106, 77-84.

Surlyk, F. \& Hurst, J. M. 1983: Evolution of the early Paleozoic deep-water basin of North Greenland Aulacogen or narrow ocean? Geology 11, 77-81.

Surlyk, F. \& Hurst, J. M. 1984: The evolution of the early Paleozoic deep-water basin of North Greenland. Bull. Geol. Soc. Am. 95, 131-154.

Trettin, H. P. \& Balkwill, H. R. 1979: Contributions to the tectonic history of the Innuitian Province, Arctic Canada. Can. J. Earth Sci. 16, 748-769. 